\title{
Pseudocyst of Spleen;
}

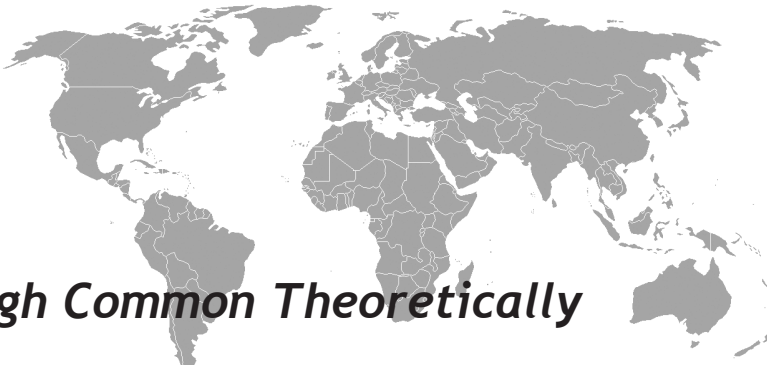

Fatih Altıntoprak, Enis Dikicier, Taner Kıvılcım, Tolga Ergönenç, Osman Nuri Dilek

Sakarya Research and Educational Hospital, Departments of General Surgery', and Anesthesiology and Reanimation ${ }^{2}$, Sakarya Turkey

Eur J Gen Med 2012;9 (Suppl 1):43-46

Received: 12.06 .2010

Accepted: 16.08 .2010
Correspondence: Fatih Altintoprak, MD Sakarya Eğitim Araștırma Hastanesi Genel Cerrahi

GSM: 905335483415, Fax: 902642751011

E-mail: fatihaltintoprak@yahoo.com

\begin{abstract}
Splenic pseudocyst is not common entity in clinical practice. First case is 28 years old woman, admitted to our clinic with complaint of epigastric pain. In radiologic examinations, a cystic lesion was detected in the spleen with the size of $12 \mathrm{~cm}$ and performed splenectomy. Second case is 26 years old man, hospitalized after detected a mass in the spleen during performed ultrasonography due to complaint of $d y$ suria. In further radiologic examinations revealed a cystic mass in the spleen with the size of $10 \mathrm{~cm}$ and splenectomy was performed. In hystopathological examination, the splenic pseudocyst was detected in both patients. In this paper, we aimed to disscus differential diagnosis and treatment options of splenic cysts under the view of literature.
\end{abstract}

Key Words: Splenic cysts, pseudocyst, splenectomy

\section{Dalağın Psödokisti}

Özet

Dalak psödokistleri klinik pratikte nadir karșılașılan lezyonlardır. Birinci olgu 28 yaşında kadın hasta, epigastrik ağrı șikayeti ile polikliniğe başvurdu. Radyolojik incelemeler sonucunda dalakta $12 \mathrm{~cm}$ çapında kistik lezyon saptandı ve splenektomi yapıldı. Ikinci olgu 26 yașında erkek hasta, disüri șikayeti nedeni ile yapılan üriner sistem ultrasonografisi sırasında dalakta kitle saptanması üzerine servise yatırıldı. Radyolojik incelemeler sonrası dalakta $10 \mathrm{~cm}$ çaplı kistik lezyon saptand ve splenektomi yapıldı. Her iki olgunun da histopatolojik incelemesi dalak psödokisti olarak sonuçlandı. Bu yazıda, dalak kistlerinin ayırıcı tanılarını ve tedavi seçeneklerini irdelemeyi amaçladık.

Anahtar kelimeler: Dalak kisti, psödokist, splenektomi 


\section{INTRODUCTION}

Pseudocysts of spleen are reported to be common in the literature, but in clinical practice, they are not so commonly faced. Classification is made as parasitic and nonparasitic in general, but some authors prefer to classify according to origin of the cells or the content of the cyst (Table 1) $(1,2)$. It is important to distinguish pseudocysts from other splenic benign or malign cyts, especially from hydatid cyts in order to follow the right treatment and management options (3-6). The aim of this paper is to discuss the criteria to differentiate splenic pseudocyts from other cysts of spleen, radiologic findings of splenic cyts and treatment choices of cystic lesions of spleen according to data present in literature.

\section{CASE 1}

A 28 year-old woman presented with epigastric pain and discomfort located at her left upper abdomen. A well demarcated, immobile mass with an impression of splenomegaly and it was palpated on left upper quadrant by physical examination. The patient had a cesarean section history a year ago which has ended in intensive care unit because of renal failure due to acute tubular necrosis that has dissolved in about a week. Complete blood count, biochemical parameters and tumor marker levels were normal. A cystic mass with a diameter of $12 \mathrm{~cm}$ which was covering the left upper quadrant, so appearing as originating from the spleen was detected on abdominal computerized tomography (CT). A magnetic resonance imaging (MRI) was performed and a cystic mass with a diameter of $11-12 \mathrm{~cm}$ originating from the spleen was detected. The lesion was reported hypointense by $\mathrm{T} 1$-weighted images, and hyperintense by $\mathrm{T} 2$-weighted images (Figure 1). It was reported homogenious inside, with a little heterogenious part at a peripheral side. Operation was planned with a diagnosis of splenic pseudocyst. Laparoscopic exploration was performed at first and a cystic mass extending from the centre of the spleen towards posterior of the stomach, which was adherent to the adjacent tissues was observed. The cyst was filled with serous fluid surrounded with a thick capsule. Because of splenic hilus was not visualized as laparoscopically, operation was switched to open procedure and splenectomy was performed following a left subcostal incision. The patient was discharged postoperatively on 7th day without complication. Histopathological examination of the splenectomy
Table 1. Classification of splenic cysts according to etiology and content of the cyst.

\begin{tabular}{ll}
\hline Class & Etiology and content \\
\hline Congenital & Real cyst \\
Inflammatory & Pyogenic, echinoccal, fungal \\
Vascular & Peliosis \\
$\begin{array}{l}\text { Posttraumatic } \\
\text { Neoplastic } \\
\text { Benign }\end{array}$ & Hematoma, pseudocysts \\
Malign & Hemangioma, lymphangioma \\
\hline
\end{tabular}

material was reported as pseudocyst originating from posterior of the spleen.

\section{CASE 2}

A 26 year-old man was admitted after detection of a cystic mass at spleen while he was having an abdominal ultrasonography for dysuria (Figure 2a). This patient had a history of hospitalization for 4 days after a traffic accident inside the car 2 years ago. Routine blood tests and tumor marker levels were normal. A well demarcated cystic mass with $8-9 \mathrm{~cm}$ diameter covering the center of the spleen was detected on MRI. The lesion was homogenious, not contrasting and hypointense by $\mathrm{T} 1$ - weighted images (Figure $2 \mathrm{~b}$ ), hyperintense by $\mathrm{T} 2$ weighted images (Figure 2c). Operation was planned with a diagnosis of posttraumatic splenic pseudocyst. A cystic mass of 10 $\mathrm{cm}$ in diameter filled with serohemorragic fluid covering the central part of the spleen was observed during the operation and splenectomy was performed. No complication occured and the patient was discharged on postoperatively 6th day. Histopathology of the splenectomy material was consistent with a pseudocyst originated from the centre of the spleen.

\section{DISCUSSION}

Cystic lesions of the spleen, parasitic or not, rarely cause clinical symptoms, they are usually diagnosed incidentally by abdominal imaging for another purpose. Localization, size and type of the cyst are the factors to make them symptomatic. It is accepted generally that a cyst with a diameter more than $4 \mathrm{~cm}$ will be symptomatic, although there is no consensus on this (7). The diameter of the cysts were over $4 \mathrm{~cm}$ in both of our 


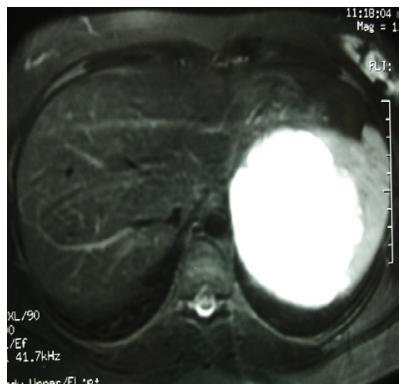

Figure 1. MRI image in transverse section : Obvious hyperintense signaling with fat supressed T2weighted images, a cystic mass covering the center of the spleen with a peripheral heterogeneity probably due to some debris.

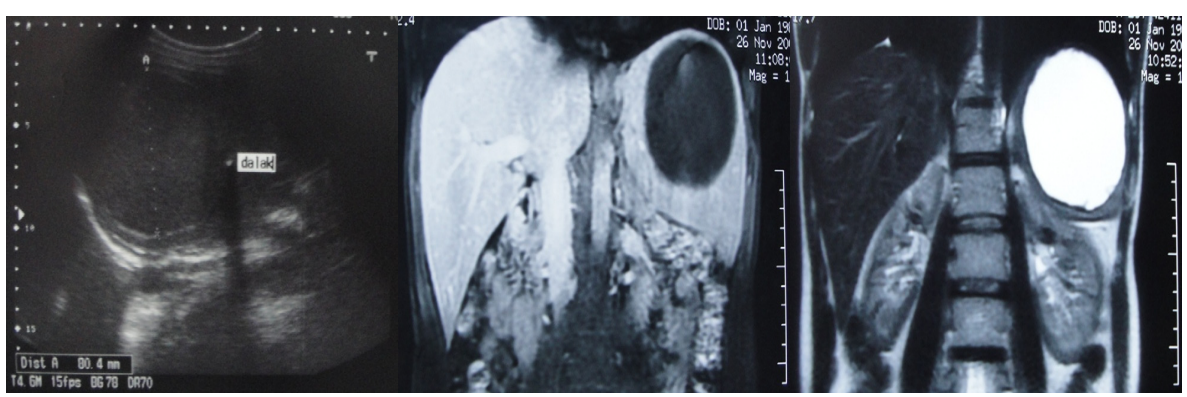

Figure 2. Ultrasonographic findings (a), cystic mass in spleen with $8 \mathrm{~cm}$ diameter, homogeneus internal structure and peripheral brightly echogenic foci with distal shadowing due to calsifications within the wall. MRI image in coronal section: (b) a cystic mass covering the splenic center, well defined border, homogeneous inside and obvious hypointense signaling with T1-weighted images, (c) obvious hyperintense signaling and homogenious inside with fat supressed $T 2$ analysis cases. One case was totally asymptomatic and diagnosed incidentally on ultrasonography, while the other one had some non spesific abdominal symptoms.

Pseudocysts of spleen have thick, fibrous walls without epithelium, which may be calcified. The most accepted etiologic theory is long term effect of posttraumatic hematomas $(1,5)$. But history of trauma is not always present for all cases. According to other suggested etiologic theories pseudocysts may be formed after infarction, inflammation or thrombosis of real cysts or they may be primary real cysts that have lost their epithelium (8). Debris inside the pseudocysts may cause a heterogenious image on ultrasonography and if there is clacification on the wall a peripheral shiny echogenicity with distal shading may also be an ultrasonographic finding. They appear as well demarcated, usually homogenious, not contrasting cystic masses on CT (1). MRI findings are usually similar with CT findings. The difference may be signal changes due to proteinous material and blood amount inside the cyst with $\mathrm{T} 1$ analysis and hyperintense signaling with $\mathrm{T} 2$ analysis. Cystic masses having homogenious structure on ultrasonography, not contrasting on CT which are hypointense with $\mathrm{T} 1$ and hyperintense with T2 on MRI were present in both of our patients.

Epithelial cysts of spleen are called real cysts that appear during the first decades of life. They may be congenital or sporadic, as well as familial. Surrounding wall contains columnar, cuboidal, or squamous epithelium (5). CEA or CA 19-9 may be detected in the epithelium immunohistochemically as these markers may be elevated in the serum (7). They are usually asymptomatic and do rarely complicate. They appear as unechoic, well demarcated cystic masses on ultrasonography. Unilocular, not contrasting if there is no trabeculation, low density cystic mass with an ill defined wall is the image seen on CT. MRI shows hyperintense signaling with $\mathrm{T} 2$ which is a typical finding for all cystic lesions (1). Ages of our cases were consistent with the age of real cysts, but tumor marker levels were normal and no family history of cystic disease were present, while both of them had history of trauma on the other hand that refered the diagnosis of pseudocyst.

Abscess of spleen is diagnosed more commonly nowadays, because of increasing numbers of immunocompromised patients due to either AIDS or therapeutic agents. Abscesses located on spleen may be solitary, multiple or multilocular. Ultrasonography presents hypoechoic or anechoic mass image with an ill defined border depending on the density of purulent material inside. If air is involved, echogenicity will be increased with some posterior shading. CT image is usually a lesion with a better border that is not contrasting. Hypointense with $\mathrm{T} 1$, hyperintense with $\mathrm{T} 2$ is the image obtained on MRI. Peripheral contrasting may accompany if a capsule is existing (9). Stomach ache, fever and elevated sedi- 
mentation rate are related clinical and laboratory features that help to differentiate abscesses from cysts, but abscesses still must be considered for differential diagnosis of cysts on spleen regarding their radiologic appearance.

Hydatid cyst disease should never be overlooked for differential diagnosis of cystic disease on spleen especially in endemic countries. Lesions developed by echinococcus granulosus may appear solitary or multiple in number. Diagnosis is usually made preoperatively by patient history, laboratory findings or radiologic images, but sometimes these findings fail to make a diagnosis. It could be favorable if there exists calsification on cyst wall or female cysts radiologically. But the radiologic images may also be non-specific, especially Gharbi-type 1 hydatid cysts may easily be confused with other splenic cysts (6). Hydatid cyst must be considered especially when a patient demonstrates other cysts on different organs including liver simultaneously concomitant with cysts on spleen in an endemic area. The lesions of our patients were solitary and no co-existing cysts on other organs were present. Patients showed no risk factor for hydatid cyst as well as no positive serological test result. Structures like germinative membrane or female vesicles were not detected as well. Cystic lesions on spleen may also occur after lymphomas with central necrosis, metastatic tumors, huge hemangiomas, and infarctions covering large areas besides those major cystic diseases.

Surgical intervention is the traditionally suggested approach if the diameter is more than $4 \mathrm{~cm}$ for a cyst which makes it easier to complicate (3). Splenectomy was the operation for all types of lesions in the past, but more conservative solutions are suggested currently because the immunological functions of the spleen is better understood and it is obvious that the risk of sepsis increases after splenectomy. Total splenectomy is suggested only for huge cysts, as well as cysts covered with splenic parenchyma or cysts located on splenic hylus (7). Partial splenectomy may be the procedure for cysts which are not so large or the ones located on superior or inferior pole, and for the cases that bleeding is not a problem. This procedure allows to preserve the spleen at least partially. Since it is realized that post operative benefits are obvious, laparoscopic intervention is the suggested surgical operation for splenic cysts currently (10). Furthermore, partial splenectomy choice is recommended to be preserved for relapsing cases or suspi- cious primary cysts; just decapsulation is reported to be enough for the rest of the cases (11). Total splenectomy was performed after the vaccinations completed via left subcostal incision since splenic hilus was not visualized as laparoscopic exploration, the cysts were large in size and located centrally in both of our cases.

Splenic cysts are rather rarely encountered in clinical practice. These cysts may be totally benign diseases or may present infectious diseases, primary malignancies and metastaic disseminations as well. The most crucial point clinically is to make the differentiation preoperatively. Therapeutic approach should allow to preserve the spleen as much as possible, but when this is not accessible, splenectomy is a treatment option especially the endemic areas of hidatydosis and if the cyst is in very large or in hilus.

\section{REFERENCES}

1. Urrutia M, Mergo PJ, Ros LH, Torres GM, Ros PR. Cystic masses of the spleen: radiologic-pathologic correlation. Radiographics 1996; 16:107-29

2. Avital S, Kashtan H. A large epithelial splenic cyst. N Eng J Med 2003; 349:2173-4

3. Macheras A, Misiakos EP, Liakakos $T$, Mpistarakis $D$, Fotiadis C, Karatzas G. Non-parasitic splenic cysts: a report of three cases. World J Gastroenterol 2005;11:6884-7

4. Kılınç N, Yaldız M, Yılmaz F, Büyükbayram H, Yılmaz $H G$, Kavak V. Splenik mezotelyal kist (bir olgu nedeniyle). T Klin Tıp Bilimleri 2002;22:406-8

5. Hansen MB, Moller AC. Splenic cysts. Surg Laparosc EndosC Percutan Tech 2004; 14:316-22

6. Adas G, Karatepe O, Altiok M, Battal M, Bender O, Ozcan $D$, et al. Diagnostic problems with parasitic and non-parasitic splenic cysts. BMC Surg 2009; 9:9 (PMID: 19476658)

7. Stoidis $C N$, Spyropoulos BG, Misiakos EP, Fountzilas $C K$, Paraskeva PP, Fotiadis Cl. Spontaneous regression of a splenic cyst: a case report and review of the literature. Cases J 2009;2:8730

8. Shousha S. Splenic cysts: a report of six cases and a brief review. Postgrad Med J 1978;54:265-9

9. Elsayes KM, Narra VR, Mukundan G, Lewis JS Jr, Menias CO, Heiken JP. MR imaging of the spleen: spectrum of abnormalities. Radiographics 2005;25:967-82

10. Tagaya N, Oda N, Furihata M, Nemoto T, Suzuki N, Kubota K. Experience with laparoscopic management of solitary symptomatic splenic cyst. Surg Laparosc Endosc Percutan Tech 2002; 12:279-82

11. Mertens J, Penninckx F, DeWever I, Topal B. Long-term outcome after surgical treatment of nonparasitic splenic cysts. Surg Endosc 2007;21:206-8 